\title{
A high level of nest predation observed in a large Sand Martin (Riparia riparia) colony
}

\author{
Tibor SzÉP ${ }^{*}$, Jenifer FÜR ${ }^{2} \&$ Edit MolNÁR ${ }^{1}$
}

Received: October 26, 2016-Accepted: November 30, 2016

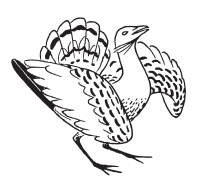

Tibor Szép, Jenifer Für \& Edit Molnár 2016. A high level of nest predation observed in a large Sand Martin (Riparia riparia) colony. - Ornis Hungarica 24(2): 46-53.

\section{this season, foxes dug a large nu} lony, comprising over 1,500 pairs. This high level of predation caused death and/or injury to between $7 \%$ and $44 \%$ of breeding individuals and lowered the reproductive success of the colony as on average $20 \%$ (between $5 \%$ and $43 \%)$ less nestlings were fledged. The level of digging showed a negative exponential growth with burrow density. Our observations show that the burrows were most at threat between $0 \mathrm{~m}$ and $0.4 \mathrm{~m}$ from the top and between $0 \mathrm{~m}$ and $1.4 \mathrm{~m}$ from the bottom of the wall. These observations show that it is critically important to decrease the number of foxes and other potential nest predators, whose numbers have increased well above 'natural' levels over the last decade, in regions where Sand Martins are nesting as this species is in drastic decline.

Keywords: predation, Riparia riparia, colony, Tisza

Összefoglalás Munkánkban megvizsgáltuk a partifecske természetes élőhelyén, a Tisza mentén lévő jelentős nagyságú telepen 2016-ban tapasztalt nagymértékủ kiásásos fészekragadozás jellemzőit és hatását. A rókák által kiásott nagyszámú üreg az 1500 páros nagyságot meghaladó nagy telepen a fészkelő üregek 39\%-nak részleges/ teljes pusztulását eredményezte. E jelentős ragadozás egyrészt a költő egyedek 7-44\%-nak pusztulását/sérülését okozta, másrészt a kirepült fiókák számának átlagosan 20\%-al való csökkenését (5-43\%) eredményezte. A rókák által kiásott üregek száma növekedett, de egyre lassuló ütemben a partfalon lévő partifecske üregek sủrúségével. A kiásásos ragadozás által legfenyegetettebb üregek a partfal felső $0,4 \mathrm{~m}$ sávjában, illetve a függőleges partfal aljától számított 0-1,4 m sávjában helyezkedtek el. A korábbi évtizedekhez képest jelentösen megnövekedett számú róka és más fészekragadozó számának csökkentése a partifecske telepek körzetében nagyon fontos e faj drasztikus csökkenést mutató hazai állományának védelme számára.

Kulcsszavak: ragadozás, Riparia riparia, telep, Tisza

${ }^{1}$ Institute of Environmental Sciences, University of Nyíregyháza, 4400 Nyíregyháza, Sóstói út 31/b, Hungary,
e-mail: partifecske@freemail.hu
${ }^{2} 4244$ Újfehértó, Radnóti Miklós utca 10., Hungary
${ }^{*}$ corresponding author

\section{Introduction}

Populations of Sand Martin (Riparia riparia) breeding along the Tisza river in Hungary have experienced sharp declines over recent decades (mean annual population growth rates: $-2.7 \%$ over the period between 1986 and 2014, T. Szép unpublished data), a pattern that is also seen in the case of other Hungarian long distance migratory bird species (Szép et al. 2012). A variety of processes are thought to underlie the declines of Afro-Palaearctic migrant species in distant areas (Vickery et al. 2014). Sand Martin, for example, breeds in large colonies in eastern Hungary 
(Szép 1991) and an increasing subsection of this population has formed a massive breeding colony exceeding 1,000 pairs over the last decade (T. Szép, unpublished data). In 2016, however, our field teams encountered large numbers of holes dug by predators within the largest colony, a river area where ca. $55 \%$ of the entire population of the river was breeding.

In the case of Sand Martin, a number of detailed studies are available that have addressed degree of aerial predation (Szép \& Barta 1992, Probst et al. 2011), with emphasis on Hobby (Falco subbuteo), the most important aerial predator (Mead \& Pepler 1975). In terms of ground-based predators (Mead \& Pepler 1975), Fox (Vulpes vulpes) and Badger (Meles meles) are the main candidates responsible for 'digging predation' of Sand Martin burrows; indeed, Persson (1987) recorded high levels of nest predation by badger in Sweden with $25 \%$ of nests destroyed.

In this report, we discuss the number of Sand Martin burrows that were destroyed either partly or fully by this kind of nest predation in the Tisza river colony during 2016, how the level of this predation depend on the density of the burrows in the walls, which kind of burrows and which where the most threatened, and what could be the influence of predation on breeding individuals and their reproductive success.

\section{Material and methods}

The Sand Martin is an aerial insectivorous bird, which usually digs new burrows after its arrival back to breeding areas in the spring in perpendicular walls of soil formed naturally (e.g. rivers) or artificially by humans (e.g. sand pits) (Cramp 1988). Each burrow comprises a 30-70 $\mathrm{cm}$ long tunnel with a nest chamber at the end.

In this study, we investigated the largest Sand Martin colony along the river Tisza at Szabolcs $\left(48.188^{\circ} \mathrm{N}, 21.488^{\circ}\right)$ during the breeding season (between middle April - beginning of August), 2016. This colony was situated along a $540 \mathrm{~m}$ long river bank, formed naturally by the flood of the river during the preceding winter. We followed the formation of the colony by taking digital pictures (Panasonic FZ1000) from the front of the colony at $6 \mathrm{~m}$ long sections along the river ( 90 sections in all, marked with numbered peg on the top of the bank), twice a week, and we counted Sand Martin burrows and measured the height of the perpendicular part of the river bank along the $6 \mathrm{~m}$ sections from these pictures using Image J software (Schneider et al. 2012). In this way, we used the daily counts of Sand Martin burrows in the studied sections to identify the number of destroyed burrows resulting from natural falls of river banks following heavy rain.

In terms of predators that operate on the ground, we identified Badger, Fox, Weasel (Mustela nivalis), Stoat (Mustela ermine), Brown Rat (Rattus norvegicus) and Domestic Cat (Felis silvestris catus) (Mead \& Pepler 1975, Persson 1987) as potential Sand Martin predators. Indeed, in the context of our integrated monitoring of the Tisza river colony (Szép et al. 2003), we also encountered additional predators including Beech Marten (Martes foina) and Wildcat (Felis silvestris) (Szép T. unpublished). However, at this colony, on the basis of footprints and smells, it is clear that foxes carried out predominant digging into nesting holes, although we were unable to estimate the number of predators. 
We were able to identify and count the number of holes dug by nest predators in our studied sections in the river bank front using pictures because the size and shape of holes and burrow entrances affected by predation are very different from normal Sand Martin burrows. Indeed, nest predators also dig into chambers from the top of the bank, an angle which was invisible from our pictures. We surveyed these holes along the top of the colony surveying $6 \mathrm{~m}$ long sections on $11^{\text {th }}$ of July 2016 (subsequent to fledging of the first Sand Martin clutches). As a pilot experiment to protect burrows, we covered the top of one $6 \mathrm{~m}$ long section of the colony with a $1 \mathrm{~m}$ wide metal net before the colonization of this section in April and found that no Sand Martin burrows were dug by predators from the top in this section.

We then randomly selected eight subcolonies along the Szabolcs colony situated in 1-6 $\mathrm{m}$ wide parts of the banks ( $1 \mathrm{~m}: 1$ piece, $2 \mathrm{~m}: 5$ pieces, $6 \mathrm{~m}: 2$ pieces), where every burrows were numbered (551 burrows) and investigated weekly with a digital endoscope (Olympus IPLEX LX videoscope) to follow breeding history of the first and additional/second clutches in the burrows (i.e. start of egg laying, clutch size, hatching, number of nestlings before fledging at the age of 15-18 days, evidence of nest predation). We measured the distance of these burrows from the top and bottom of the perpendicular part of river bank from pictures. In the case of these intensively studied sections, we directly investigated the holes dug by predators in the front and top of the subcolonies.

We used parametric and non-parametric statistical tests depending on the distribution of the data using SPSS 18.0 (Norris et al. 2012). We modeled the of digging predation and burrow density with negative exponential growth models (Bates \& Watts 1988), using the nls () function of the R statistical software (R Core Team 2015).

\section{Results}

\section{Sand Martin burrows and holes dug by predators in the colony}

Across the studied colony, 2,776 burrows were made by Sand Martins in 2016. The birds started digging on the $23^{\text {rd }}$ of April and the first $10 \%$ of burrows were complete by the $1^{\text {st }}$ of May, the first $50 \%$ by the $16^{\text {th }}$ of May, and the first $90 \%$ by the $3^{\text {rd }}$ of June (Figure 1). Burrows were dug into 50 separate $6 \mathrm{~m}$ long sections (mean number of burrow/section $=55.32, \mathrm{SD}=49.044$, median=30, minimum $=2$, maximum $=206, \mathrm{n}=50)$. The density of Sand Martin burrows varied between 0.81-17.04 burrows $/ \mathrm{m}^{2}$ (mean=5.591, SD=4.267, median=4.3, $\mathrm{n}=45$ ).

Following days with heavy rain and partial predator digging activities, 1,603 burrows had collapsed by falling down the river banks by August; by the beginning of July (the end of the first clutch fledging period), 991 burrows had disappeared (36\% of all burrows).

We identified 280 holes that were dug by predators in front of the colony during the breeding season. This digging started on the $25^{\text {th }}$ of April, with the most intense periods between $1^{\text {st }}-16^{\text {th }}$ of May, $20^{\text {th }}-30^{\text {th }}$ of May and $6^{\text {th }}$ of June $-11^{\text {th }}$ of July (Figure 1 ). This kind of nest predation occurred at 35 pieces of $6 \mathrm{~m}$ long sections from the 45 sections where incubation/ 


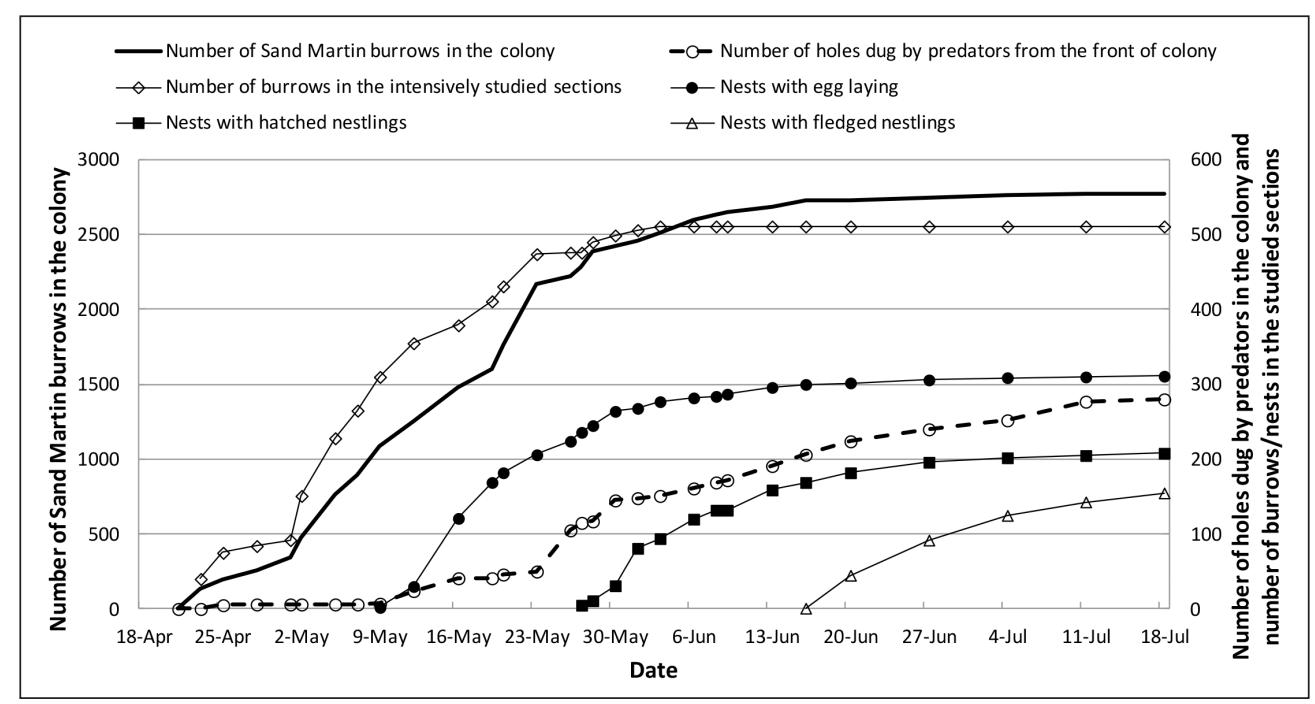

Figure 1. Number of Sand Martin burrows in the colony and number of holes dug from the front of the colony by nest predators during the 2016 breeding season. The number of burrows, nests with eggs, nests with hatched nestlings, and nests with fledged nestlings in the eight intensively studied subcolonies are shown

1. ábra Partifecske fészkelő üregek és a ragadozók által a partfal oldaláról kiásott üregek száma a 2016-os költési időszakban a szabolcsi telepen. Az intenzíven vizsgált 8 teleprészlet esetében a fészkelő üregek száma, a tojásos, kikelt fiókás és kirepült fiókás fészkek száma megadva a teljes költési időszakra

nestling rearing digging were possible (5 sections there were only burrow digging) and our analysis demonstrates a significant positive correlation between the number of holes dug at the front of the colony and the density of the burrows in the section $(r=0.698, n=45$, $\mathrm{P}<0.001$, Spearman rank correlation).

We identified 128 holes dug from the top of the colony by predators during the breeding season up until the end of the fledging of the first clutches. This kind of predation occurred in 23 distinct $6 \mathrm{~m}$ long sections, and there was a significant positive correlation between the holes dug from the top and the density of burrows in the section $(r=0.671, n=45, P<0.001$, Spearman rank correlation).

Considering both kind of nest predation (dug from front and top direction), the number of dug holes increased with the density of burrows (Figure 2). The fitted negative exponential model: (the standard errors and the $p$-values of the estimated parameters are: $\mathrm{SE}=3.49$ $(p=0.1088), S E=3.09(p<0.0001), S E=0.09(p=0.0394)$, respectively. The estimated maximum number of holes is about $21 /$ section.

\section{Breeding and predation in intensively studied subcolonies}

The number of burrows in the eight subcolonies we studied comprised $18.4 \%$ of the entire colony. In these subcolonies, digging started on the $23^{\text {rd }}$ of April, and the first $10 \%$ of all burrows were completed by the $25^{\text {th }}$ of April, the first $50 \%$ by the $9^{\text {th }}$ of May, and the first $90 \%$ 
by the $20^{\text {th }}$ of June (Figure 1). The arrival of birds to these subcolonies was about one week earlier than the rest of the colony.

We investigated all burrows in these eight subcolonies with an endoscope and determine that eggs were laid in 311 burrows, $60.9 \%$ of the total $(95 \%$ CI: $56.6 \%-65.1 \%) 511$ burrows. The level of burrow occupancy was similar to previously reported, at $60 \%$ (Szép 1990), while the level of burrow disappearance by river bank collapse (34.6\%, 177 burrows) was similar as in the colony during the rearing of the first clutches.

Egg laying started on the $9^{\text {th }}$ of May (median: $19^{\text {th }}$ of May) and by the $25^{\text {th }}$ of May eggs had been laid in $90 \%$ of nests $(\mathrm{n}=208)$ (Figure 1). Of these, $66.9 \%$ hatched, starting on the $27^{\text {th }}$ of May (median: $4^{\text {th }}$ of June), and by the $24^{\text {th }}$ of June hatching has commenced

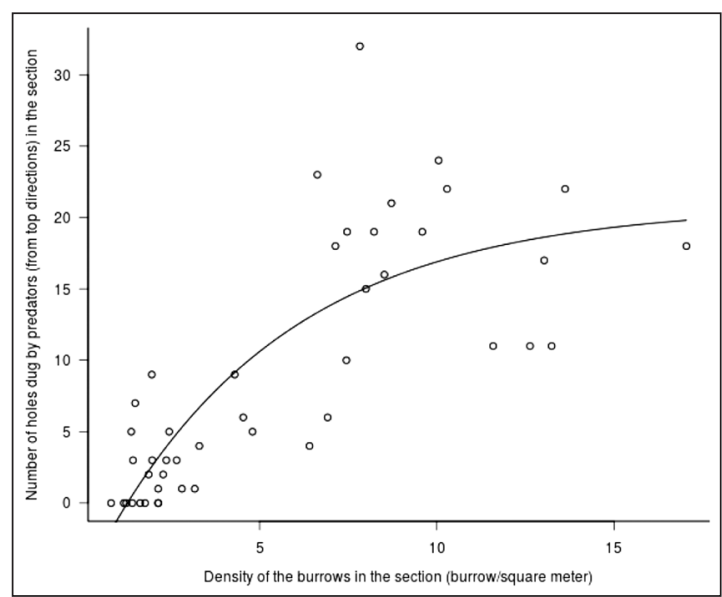

Figure 2. Number of holes dug by predators (from front and top of the colony) in the $6 \mathrm{~m}$ long sections of the colony as well as the density of burrows (burrow $/ \mathrm{m}^{2}$ ) in these sections and the fitted negative exponential growth model

2. ábra A 6 m hosszú lakott szakaszokon a ragadozók által kiásott üregek száma (a partfal oldaláról és tetejéről) és a partifecske üregek sűrűsége (üreg $/ \mathrm{m}^{2}$ ) és az illesztett negatív exponenciális növekedési görbe in $90 \%$ of all nests $(\mathrm{n}=208)$. Nestlings reached $15-18$ days old in $50.5 \%(\mathrm{n}=157)$ of nests that contained eggs; fledging started on the $16^{\text {th }}$ of June (median: $24^{\text {th }}$ of June), and by the $11^{\text {th }}$ of July young in $90 \%$ of nests had fledged.

In the eight subcolonies, 26 holes were dug by predators from the front of the colony. These 26 holes destroyed partly/fully 76 Sand Martin burrows (mean value: 2.923 burrows/ dug holes from front; $95 \%$ CI: 2.228-4.247). In these cases, predation started on the $30^{\text {th }}$ of May, and $50 \%$ of the partly/fully destroyed burrows were dug until the $13^{\text {th }}$ of June while by the $5^{\text {th }}$ of July $90 \%$ had been dug by predators. This kind of predation occurred mainly during the pairing, incubation and hatching periods. Breeding adults were potentially influenced (killed/injured and/or breeding were abandoned) in $43.4 \%$ of these nests, incubating adults and eggs were killed/destroyed in $7.9 \%$ and nestlings were killed $21.1 \%$ of the nests. There were successful breeding only in $10.5 \%$ of these nests (in $17.1 \%$ of these nests the influence was not identifiable).

In two subcolonies, we were able to examine the number of holes dug in total by predators from the top of the colony ( 15 holes) as well as the number of Sand Martin burrows destroyed either partly or fully by this predation (31 burrows) and found that the mean value was 2.067 burrows/dug holes from top (95\% CI: 1.516-3.247). Across the eight subcolonies, 38 nests in total were dug from the top of the colony. This predation started on $9^{\text {th }}$ of May, and by the $20^{\text {th }}$ of June $50 \%$ of the partly/fully destroyed burrows had been dug, while by the $10^{\text {th }}$ of July $90 \%$ had been dug by the predators. This kind of predation occurred 
mainly during the periods of nestling rearing; nestlings were killed in $42.1 \%$ of nests, breeding adults were potentially influenced (killed/injured and/or breeding were abandoned) in $15.8 \%$ of these nests, and in none of these nests the nestlings were able to reach fledging age $(0 \%$ ) during the first clutch period (in $26.3 \%$ of nests predation occurred during the period of additional/second clutches and the influence was not identifiable in a further $15.8 \%$ of nests).

Distance of burrows from the top and bottom of the perpendicular part of the river bank was significantly different among burrows predated from front or top of the colony and burrows that lacked nest predation (i.e. distance from the top of the bank: $\mathrm{F}=119.329, \mathrm{df}=2$, 105.425, $\mathrm{P}<0.001$; distance from the bottom of the bank: $\mathrm{F}=24.072$, $\mathrm{df}=2,92.829, \mathrm{P}<0.001$, Welch robust test of equality of means) (Table 1). Burrows predated from the top of the wall were mainly situated in the top $0.4 \mathrm{~m}$ wide layer $(90 \%)$ (Table 1), while those predated from the front of the colony were situated in the lower layer but across a wider range from the bottom of the wall with $90 \%$ between $0-1.4 \mathrm{~m}$ (Table 1 ).

Of the 551 burrows we investigated, $140(25.4 \%)$ contained nestlings, and the mean number of nestlings before the fledging (at 15-18 days old) was 1.02 nestlings/burrow $(\mathrm{SD}=1.741, \mathrm{n}=551)$. The number of burrows dug partly/fully by predators was $114,20.7 \%$ of all studied burrows, and in these there was a significantly lower number of fledged nestlings (mean $=0.605, \mathrm{SD}=1.520, \mathrm{n}=114$ ) than in burrows that did not experience this kind of predations (mean $=1.124, \mathrm{SD}=1.780, \mathrm{n}=437$ ) (mean difference $=-0.518, \mathrm{SD}=0.166,95 \% \mathrm{CI}$ : $-0.193-0.843, \mathrm{t}=3.124, \mathrm{df}=201.561, \mathrm{P}=0.002$, Welch test $)$.

\section{Estimated influence of nest predators on the colony}

The estimated mean number of burrows dug by predators was 1,083 (minimum=818, maximum $=1,605$ ) based of the mean number of burrows influenced by holes dug from the front and top of the colony $(95 \% \mathrm{CI}$ ). In the colony, $39 \%$ (minimum $=29.5 \%$, maximum $=57.8 \%$ ) of the 2,776 burrows suffered because of digging predation, and the number of fledged

Table 1. Distance from the top and bottom of the wall of predated (dug from the front of the colony and from the top of the colony) and unpredated burrows in the eight intensively studied Sand Martin subcolonies at Szabolcs in 2016

1. táblázat A kiásásos ragadozás által érintett és nem érintett partifecske üregek távolsága a partfal tetejétől és aljától az intenzíven vizsgált 8 teleprészleten, a Szabolcs térségében lévő telepen 2016-ban (Átlag, medián, szórás és mintaszám megadva a nem kiásott, a partfal oldaláról és a partfal tetejéről kiásott üregek esetében)

\begin{tabular}{|l|c|c|c|c|c|c|}
\hline \multirow{2}{*}{} & \multicolumn{4}{|c|}{ Distance from the top of the bank $(\mathbf{m})$} & \multicolumn{3}{|c|}{ Distance from the bottom of the bank $(\mathbf{m})$} \\
\cline { 2 - 7 } & No predation & $\begin{array}{c}\text { Predation } \\
\text { from the front }\end{array}$ & $\begin{array}{c}\text { Predation } \\
\text { from the top }\end{array}$ & No predation & $\begin{array}{c}\text { Predation } \\
\text { from the front }\end{array}$ & $\begin{array}{c}\text { Predation } \\
\text { from the top }\end{array}$ \\
\hline Mean & 0.695 & 0.813 & 0.337 & 1.040 & 0.832 & 1.195 \\
\hline Median & 0.800 & 0.800 & 0.400 & 1.000 & 0.800 & 1.200 \\
\hline SD & 0.294 & 0.274 & 0.132 & 0.317 & 0.399 & 0.177 \\
\hline $\mathrm{n}$ & 437 & 76 & 38 & 437 & 76 & 38 \\
\hline
\end{tabular}


nestlings was lower at an average of 561 individuals (minimum=158, maximum=1,354), taking into account mean differences between predated and not predated burrows. Thus, the estimated number of lost nestlings is around $20 \%$ (minimum $=5 \%$, maximum $=43 \%$ ) of the potential total number of fledged nestlings in the colony (ca. 3,100 nestlings) estimated to be present if nest predation had not occurred.

Our results show that this kind of predation causes death or serious injury to breeding birds in $15-43 \%$ of burrows dug by predators. The estimated number of adult individuals affected by predation of this kind was between 245 and 1,380 birds, $7-44 \%$ of the total number of individuals out of an estimated 1,691 (minimum=1,571, maximum=1,807) total breeding pairs in the colony.

\section{Discussion}

Nest predation by foxes digging into Sand Martin burrows reached a very high level in 2016, affecting $39 \%$ of burrows in a colony with 1,500 breeding pairs of birds. This high level of predation caused death or injury to $7-44 \%$ of the breeding individuals and led to a lower level of reproduction in the colony as an average of 20\% (5-43\%) less nestlings fledged.

The threat of digging predation from the top of colony is higher because it affects nests containing nestlings; no fledging was possible from nests predated in this way. However, in the case of burrows dug from the front of the colony, we did find found nests containing fledged nestlings as this kind of predation mostly threatens breeding adults during the pairing and incubation periods.

The level of digging predation increased with density of the burrows, but when higher than a specific density level (ca. 8 burrows $/ \mathrm{m}^{2}$ ) the number of holes dug by predators did not increase in accordance with the dilution effect (Foster \& Treherne 1981). However in the case of large density of burrows, one hole dug by predators could harm more burrows, which needs to be considered as well when potential of dilution effect expected to reduce predation threat.

Distance of burrows from both the top and bottom of the perpendicular part of the wall is an important factor determining threat from digging predation. Our results show that the positions most at threat are the $0-0.4 \mathrm{~m}$ layer from the top of the wall, because of the predation from the top of the colony and - the 0-1.4 m layer from the bottom of the wall, because of the predation from the front of the colony. Breeding walls with the minimum $2 \mathrm{~m}$ perpendicular height could provide more safe position for burrows against digging predation, however the chance of falling the breeding wall after heavy rains increase with the height of the wall, depending on the type of soil (Szép T. pers. obs.), which need to consider when breeding habitats prepared artificially for Sand Martin colonies.

Reducing the threat of nest predation is very important in the case of this species which population shows drastic decline. To decrease the numbers of Foxes and other potential nest predators (e.g. Beech Marten, Badger) which numbers increased above the former "natural" level during the last decade in the area of Sand Martin colonies, especially around large colonies is very important. The use and development of mechanical protection for Sand Martin burrows against digging (e.g. covering the top and front part of the colony with metal 
net with proper mesh size) and developing chemical protection with natural compounds (e.g. capsaicin) (Baylis et al. 2012) for deterring predators are necessary as well for the protection of large colonies.

\section{Acknowledgements}

We thank Ákos Pelenczei, János Danku, Annamária Danku, Zsolt Nagy, the members of the local chapter of MME/BirdLife Hungary for their critical help with field work and to Gareth Dyke for help English polishing of the manuscript. We thank to the reviewer for useful suggestions to the statistical analysis. We also thank the local chapter of MME/BirdLife Hungary for providing infrastructure and resources for field work, and Béla Habarics, head of the Szatmár-Bereg Landscape Protected Area, for providing materials for this research. The endoscopic studies reported in this paper were carried out with the permission of the Hungarian National Inspectorate for Environment, Nature and Water (OKTF-KP/7340-11/2015).

\section{References}

Bates, D. M. \& Watts, D. G. (ed.) 1988. Nonlinear Regression Analysis and Its Applications. - Wiley

Baylis, S. M., Cassey, P. \& Hauber, M. E. 2012. Capsaicin as a deterrent against introduced mammalian nest predators. - The Wilson Journal of Ornithology 124: 518-524.

Cramp, S. 1988. The birds of the Western Palearctic, Vol. 5. - Oxford University Press, pp. 235-248.

Foster, W. A. \& Treherne, J. E. 1981. Evidence for the dilution effect in the selfish herd from fish predation on a marine insect. - Nature 293: 466-467. DOI: 10.1038/293466a0

Mead, C. J. \& Pepler, G. R. M. 1975. Birds and other animals at Sand Martin colonies. - British Birds 68: 89-99.

Norris, G., Faiza, Q., Dennis, H. \& Duncan, C. 2012. Introduction to statistics with SPSS for social science. Pearson, Harlow

Persson, C. 1987. Age structure, sex ratios and survival rates in a south Swedish Sand Martin (Riparia riparia) population, 1964 to 1984. - Journal of Zoology 1: 639-640. DOI: 10.1111/j.1096-3642.1987.tb00749.x

Probst, R., Nemeschkal, H. L., McGrady, M., Tucakov, M. \& Szép, T. 2011. Aerial hunting techniques and predation success of Hobbies Falco subbuteo on Sand Martin Riparia riparia at breeding colonies. - Ardea 99: 9-16. DOI: 10.5253/078.099.0102

R Core Team 2015. R: A language and environment for statistical computing. - R Foundation for Statistical Computing, Vienna, Austria, URL https://www.R-project.org/.

Schneider, C. A., Rasband, W. S. \& Eliceiri, K. W. 2012. NIH Image to ImageJ: 25 years of image analysis. - Nature Methods 9: 671-675.

Szép, T. 1990. Estimation of abundance and survival rate from capture-recapture data of Sand Martin (Riparia riparia) ringing. - Ring 13: 205-213.

Szép, T. 1991. A Tisza magyarországi szakaszán fészkelő partifecske (Riparia riparia L., 1758) állomány eloszlása és egyedszáma [Size and distribution of Sand Martin population along the Hungarian section of the river Tisza]. - Aquila 98: 111-124.

Szép, T. \& Barta, Z. 1992. The threat to Bank Swallows from the Hobby at a large colony. - Condor 94: 10221025. DOI: $10.2307 / 1369304$

Szép, T., Szabó, D. Z. \& Vallner, J. 2003. Integrated population monitoring of Sand Martin Riparia riparia - an opportunity to monitor the effects of environmental disasters along the River Tisza. - Ornis Hungarica 1213: $169-182$.

Szép, T., Nagy, K., Nagy, Zs. \& Halmos, G. 2012. Population trends of common breeding and wintering birds in Hungary, decline of long-distance migrant and farmland birds during 1999-2012. - Ornis Hungarica 20: 1363. DOI: 10.2478 /orhu-2013-0007

Vickery, J. A., Ewing, S. R., Smith, K. W., Pain, D. J., Bairlein, F., Skorpilova, J. \& Gregory, R. D. 2014. The decline of Afro-Palaearctic migrants and an assessment of potential causes. - Ibis 156: 1-22. 